\title{
Program Layanan Bimbingan Konsep Diri (Self Concept) Pada Siswa Tunalaras
}

\author{
Achmad Sofyan Hanif (UNJ) \& \\ Sujarwanto PLB FIP Unesa, email: jarwanto_plb@yahoo.com
}

\begin{abstract}
Abstrak; Penelitian ini betujuan untuk menemukan program layanan bimbingan konsep diri pada anak tunalaras di SLB/E Surabaya. Hasil penelitian menunjukkan bahwa: 1) masih belum optimal mendapat bimbingan konsep diri guna menumbuhkan kesadaran pentingnya diri dalam menempatkan diri; 2) kendala penanganan konsep diri melalui bimbingan masih cukup banyak terutama pada sistem pendidikan di SLB yang belum memandang perlu adanya fungsi Bimbingan Konseling; 3) Perlunya penerapan bimbingan yang multiteknik dalam setiap penanganan kasus yang terjadi pada siswa termasuk persoalan konsep diri siswa tunalaras. Teknik-teknik yang diterapkan di SLB/E Surabaya adalah desensitisasi sistematik, untuk mengeliminasi perilaku-perilaku siswa yang mengarah pada tindakan kebosanan, rational emotif terapy (RET) untuk menanggulangi keyakinan-keyakinan siswa tentang konsep diri yang tidak sesuai dengan kebutuhan dan kemampuannya, serta layanan informasi melalui kegiatan bermain peran, eksperimen bersama dan diskusi. Pada 4 (empat) subjek yang dikenakan dalam uji coba terbatas menunjukkan adanya perubahan konsep diri ke arah yang lebih positif seperti: frekuensi penyimpangan perilaku sosial semakin berkurang seperti berkata sopan, pakaian mulai rapi dsb, siswa tidak lagi melakukan kebiasaan menunggu bimbingan guru kelasnya atau instrukturnya apabila mengerjakan tugas sekolah, berdasarkan laporan dari orangtua siswa tidak lagi melakukan kebiasaan membiarkan pekerjaan yang ia kerjakan sendiri, tetapi mulai diringkas sendiri atau ditata seperti semula, siswa mulai dapat memahami bahwa dirinya itu bagian dari lingkungan sekolah atau lingkungan keluarga.
\end{abstract}

Kata kunci: layanan bimbingan, konsep diri, tunalaras

\begin{abstract}
The purpose of this research is to find the guiding self-concept service program for unsociable children in SLB/E Surabaya. The result shows that: 1) was not still optimal yet to get guiding self-concept for developing aware of the importance the self in positioned self; 2) the issue of overcoming self concept through guiding was large enough especially to the education system in special school which did not view yet the need of counseling function; 3) the need of guiding application which multi technique in every overcoming problem that happens among the student including self concept issue of unsociable students. The technique applied in SLB/E Surabaya was systematic desensitization, to eliminate the student's behavior which lead to boring action, Rational Emotive Therapy to prevent the student's belief about self concept which was inappropriate to their need and skill, and information service through role play activity, experiment to gather and discussion. For the four subjects which included in limited trial showed that there was change self concept to the more positive such as; social behavior deviation frequency decreased more like saying politely, neat clothing, etc., the students did not do the habit anymore to wait the teacher or instructor when performing the school task, based on the parent report, the students did not do the habit anymore that was not to pay attention the job, but started to be summarized or organized as the beginning position, the students started to be able to understand the they were a part of the school or family environment.
\end{abstract}

Key words: Guiding service, self concept and unsociable 


\section{Pendahuluan}

Layanan pendidikan pada dasarnya dapat diberikan kepada anak normal dan anak luar biasa atau anak yang memiliki kebutuhan khusus (special needs). Sehubungan dengan anak yang memiliki kebutuhan khusus, Winzer (1990), mengemukakan: Special Needs is an educational term used to designate pupils who require special education. Yang dimaksudkan kebutuhan khusus adalah suatu istilah dalam pendidikan yang digunakan untuk menunjuk pada siswa yang memerlukan pendidikan khusus (pendidikan luar biasa). Salah satu anak yang memerlukan kebutuhan khusus, di antaranya anak tunalaras.

Anak tunalaras menurut Kauffman (1997), adalah anak-anak yang mengalami gangguan perilaku sebagai anak yang secara nyata dan menahun merespon lingkungan tanpa ada kepuasan pribadi namun masih dapat diajarkan perilaku-perilaku yang dapat diterima oleh masyarakat dan dapat memuaskan pribadinya.

Dalam memberikan layanan pendidikan anak tunalaras kenyataannya tidak dapat berjalan dengan mulus, akan tetapi dihadapkan dengan berbagai tantangan maupun masalah yang diakibatkan oleh faktor intern (kondisi kecacatannya), maupun faktor ekstern (lingkungan keluarga, sekolah dan masyarakat), di antaranya masalah pribadi, keluarga, karir, sosial, belajar, dan sebagainya.

Khususnya bagi siswa tunalaras yang sudah menempuh pendidikan pada tingkat SLTPLB, SMLB, dan Rehabilitasi Pravokasional ini sudah menginjak usia remaja atau dewasa awal dan sebagian dari mereka diikuti dengan inteligensi yang rata-rata atau di bawah normal, yaitu kurang lebih 95 ke bawah. Peserta didik yang IQ-nya kurang dari 95 mereka mengalami permasalahan yang sangat kompleks.

Anak tunalaras yang mengalami penyimpangan perilaku sosial, secara sepintas sulit diduga bahwa dirinya ada gangguan perilaku. Gangguan perilaku ini dapat diamati dan ditemukan gejalagejalanya jika secara bersama-sama berkomunikasi dan bergaul dengan mereka dalam kurun waktu tertentu.

Hasil observasi pendahuluan dan wawancara dengan guru tentang sikap guru terhadap siswa di SLB/E Surabaya, mereka pada umumnya bersikap wajar dan penuh perhatian, namun masih sebatas apa yang dipersepsikan dan bersifat insidental. Oleh karena itu, guru akan melakukan bimbingan terhadap siswanya, hanya apabila siswa tersebut melakukan perilaku yang negatif atau kurang etis menurut norma sopan santun maupun agama. Sebagai contoh, "siswa berciuman dengan pacarnya di hadapan guru tanpa ada keraguan", "menangis dan tidak mau pulang sekolah sebelum dicium pacarnya", "siswa laki-laki memegang pantat dan payudara teman sekelasnya pada waktu istirahat" bahkan "tindakan destruktif memukul-mukul benda di sekitarnya ketika emosional tidak terkendali" (temuan studi pendahuluan).

Perilaku siswa seperti pada contoh di atas menggambarkan adanya ketidakmampuan siswa dalam mengendalikan diri berkaitan dengan perilaku dirinya atau yang dikenal dengan konsep diri (self concept) nya rendah. Kondisi demikian dapat terjadi selain karena faktor lingkungan dapat pula karena faktor rendahnya tingkat intelektual (IQ), sehingga anak tidak mampu mempersepsi dengan baik suatu nilai yang bersifat abstrak, diantaranya masalah pacaran, masalah pertengkaran atau masalah menentang gurunya. Dalam hal ini guru berfungsi sebagai pembimbing terhadap siswanya, hanya apabila siswa tersebut melakukan perilaku yang negatif atau kurang etis menurut norma baik sopan santun maupun agama. Artinya bimbingan yang diberikan guru hanya secara insidental berupaya memberikan pengarahan atau informasi bahwa tindakan itu tidak benar. Walaupun bersifat insidental, guru, wali kelas dan kepala sekolah sudah berusaha menasehati seoptimal mungkin.

Posisi peranan guru di samping mengajar juga sebagai pembimbing telah ditegaskan oleh Depdikbud (1999:31). Sebagaimana tertuang dalam Pedoman Bimbingan di Sekolah mengatakan bahwa peranan guru mata pelajaran dan pelatih dalam pelayanan bimbingan meliputi a) membantu memasyarakatkan pelayanan bimbingan kepada siswa; b) membantu guru pembimbing/ konselor mengidentifikasi siswa yang memerlukan layanan bimbingan; c) Mengalihtangankan siswa yang memerlukan layanan bimbingan kepada guru pembimbing/konselor; d) menerima siswa alih tangan dari pembimbing atau konselor, yaitu 
siswa yang menurut guru pembimbing atau konselor memerlukan layanan pengajaran khusus (seperti pengajaran perbaikan, dan program pengayaan); e) membantu mengembangkan suasana kelas, hubungan guru, siswa dan hubungan siswa-siswa yang menunjang pelaksanaan pelayanan bimbingan; f) memberikan kesempatan dan kemudahan kepada siswa yang memerlukan layanan atau kegiatan bimbingan untuk mengikuti atau menjalani layanan atau kegiatan yang dimaksudkan; g) berpartisipasi dalam kegiatan khusus penanganan masalah siswa, seperti pembahasan kasus; dan h) membantu pengumpulan informasi yang diperlukan dalam rangka penilaian layanan bimbingan dan upaya tindak lanjutnya.

Mengingat SLB-E menggunakan sistem guru kelas dan sebagian ada yang guru mata pelajaran /bidang studi maka di antara guru yang mengajar di kelas tersebut ada salah satu guru yang ditugaskan sebagai wali kelas, dengan tugas: a) membantu guru pembimbing/konselor melaksanakan tugas-tugas khusus di kelas yang menjadi tanggung jawabnya, b) membantu guru mata pelajaran atau pelatih melaksanakan peranannya dalam pelayanan bimbingan, khususnya di kelas yang menjadi tanggung jawabnya, c) membantu memberikan kesempatan dan kemudahan bagi siswa, khususnya di kelas yang menjadi tanggung jawabnya (Depdikbud, 1999:31).

Chauhan (1979:63), membagi kebutuhan remaja atas tiga bagian, yaitu 1) Physiological needs, merupakan kebutuhan dasar seperti makanan, minuman, oksigen dan kebutuhan seksual; 2) Social or status needs, meliputi kebutuhan akan status, kebebasan, rasa aman dan kasih sayang, dan 3) Ego or integrative needs, kebutuhan mendapatkan pandangan hidup yang baik dan kebutuhan mendapatkan kemampuan yang sesuai untuk kebahagiaan masa depannya.

Memperhatikan adanya gejala-gejala penyimpangan perilaku sosial pada siswa SLTPLB di SLB/ E Surabaya, dengan indikator seperti tingkat inteligensi siswa rendah, adanya gangguan bicara yang mengakibatkan sulit berkomunikasi dengan orang lain, sehingga mereka sulit mengungkapkan pikiran dan kehendaknya, serta sikap orang tua yang cenderung over protection dan rejection. Sementara guru belum memposisikan dirinya sebagai guru BP maka berdasarkan kondisi objektif tersebut mengisyaratkan perlunya kajian kemitraan aktual dalam upaya pengatasannya.

Anak tunalaras memiliki penghayatan yang keliru, baik terhadap dirinya sendiri maupun terhadap lingkungan sosialnya. Mereka menganggap dirinya tidak berguna bagi orang lain dan merasa tidak berperasaan. Oleh karena itu, timbul kesulitan apabila akan menjalin hubungan dengan mereka, ingin mencoba mendekati dan menyayangi mereka, dan apabila berhasil sekalipun, mereka akan menjadi sangat bergantung kepada seseorang yang pada akhirnya dapat menjalin hubungan sosial dengannya.

Atas dasar uraian di atas rumusan permasalahan sebagai berikut: a) Kegiatan apa yang selama ini dilakukan oleh guru, wali kelas dan orang tua dalam menjalankan tugas layanan bimbingan konsep diri pada siswa SLB-E Surabaya?; b) Kendala-kendala apakah yang dihadapi oleh guru, wali kelas dan orang tua siswa untuk menerapkan layanan bimbingan konsep diri di SLB-E Surabaya?; c) Apa saja bentuk dukungan system yang perlu dalam pelaksanaan layanan bimbingan perilaku sosial berupa bimbingan konsep diri yang dilakukan oleh guru, wali kelas dan orang tua siswa? d) Bagaimanakah bentuk program layanan bimbingan konsep diri yang ideal yang dapat diterapkan oleh guru, wali kelas dan orang tua siswa dalam melakukan tugasnya?

Penelitian ini bertujuan untuk menemukan program layanan bimbingan konsep diri yang dapat diterapkan oleh guru, wali kelas dan orang tua dalam membantu menangani permasalahan perilaku sosial siswa tunalaras SLB/E Surabaya.

\section{Kajian Literatur}

\section{Pengertian Tunalaras}

Menurut Kauffman (1997) yang dimaksud dengan anak tunalaras adalah anak-anak yang mengalami gangguan perilaku sebagai anak yang secara nyata dan menahun merespon lingkungan tanpa ada kepuasan pribadi namun masih dapat diajarkan perilaku-perilaku yang dapat diterima oleh masyarakat dan dapat memuaskan pribadinya.

Banyak teori yang membahas konsep diri dengan berbagai dimensi, seperti dimensi 
fisiologis, dimensi sosial, dimensi intelektual dan dimensi moral. Ahli lain memberikan batasan konsep diri itu sebagai berikut: "Self-concepts can be defined as the individual's total perceptual appraisal of him or herself (phisically, socially, and intellectually) (De Polito,1997)".

Sullivan (1953) menjelaskan bahwa jika kita diterima orang lain, dihormati dan disenangi karena keadaan diri kita, kita akan cenderung bersikap menghormati dan menerima diri kita. Sebaliknya, bila orang lain selalu meremehkan, menyalahkan, dan menolak, kita akan cenderung tidak akan menyenangi diri kita. Ternyata, orangorang yang dinilai baik oleh orang lain, cenderung memberikan skor yang tinggi juga dalam menilai dirinya. Artinya, harga dirinya sesuai dengan penilaian orang lain terhadap dirinya.

Eksperimen lain yang dilakukan Gergen (1965) menunjang penemuan ini. Pada satu kelompok, subjek-subjek eksperimen yang menilai dirinya dengan baik diberi peneguhan dengan anggukan, senyuman atau pernyataan mendukung pendapat mereka. Pada kelompok lain, penilaian positif tidak ditanggapi sama sekali. Kelompok pertama menunjukkan peningkatan citra diri yang lebih baik, karena mendapat sokongan dari orang lain. Tidak semua orang lain mempunyai pengaruh yang sama terhadap diri kita. Ada yang paling berpengaruh, yaitu orang-orang yang paling dekat dengan diri kita. Dari merekalah, secara perlahan-lahan kita membentuk konsep diri kita. Senyuman, pujian, penghargaan, pelukan mereka menyebabkan kita menilai diri kita secara positif. Sebaliknya ejekan, cemoohan dan hardikan membuat kita memandang diri kita secara negatif.

Konsep diri merupakan factor yang sangat menentukan dalam komunikasi interpersonal, karena setiap orang bertingkah laku sedapat mungkin sesuai dengan konsep dirinya. Apabila seseorang menganggap dirinya sebagai orang yang rajin, ia akan berusaha melakukan pekerjaan secara baik. Jika seorang gadis merasa wanita menarik, maka akan berusaha berpakaian serapi mungkin dan menggunakan kosmetik yang tepat. Hubungan konsep diri dengan perilaku dapat disimpulkan dengan ucapan para pengajar berpikir positif "You don't think what you are, you are what you think".
Menurut William D. Brooks dan Philip Emmert (dalam De Polito,1977), ada 4 tanda orang yang memiliki konsep diri yang negatif. Pertama, ia peka pada kritik. Orang ini sangat tidak tahan kritik yang diterimanya dan mudah marah. Bagi orang ini, koreksi seringkali dipersepsikan sebagai usaha untuk menjatuhkan harga dirinya. Kedua, responsif sekali terhadap pujian. Walaupun berpura-pura menghindari pujian, ia tidak dapat menyembunyikan antusiasmenya pada waktu menerima pujian. Bagi orang ini segala macam embel-embel yang menunjang harga dirinya menjadi pusat perhatiannya. Bersamaan dengan kesenangannya terhadap pujian, merekapun bersikap hiperkritis terhadap orang lain. Ia selalu mengeluh, mencela atau meremehkan apa pun dan siapa pun. Mereka tidak pandai dan tidak sanggup mengungkapkan penghargaan atau pengakuan pada kelebihan orang lain. Ketiga, memiliki sikap hiperkritis, sehingga cenderung merasa tidak disenangi orang lain. Ia merasa tidak diperhatikan. Karena itulah ia bereaksi pada orang lain sebagai musuh, sehingga tidak dapat melahirkan kehangatan dan keakraban persahabatan. Ia tidak akan pernah mempersalahkan dirinya, tetapi akan menganggap dirinya sebagai korban dari sistem sosial yang tidak beres. Keempat, bersikap pesimis terhadap kompetisi seperti terungkap dalam keengganannya untuk bersaing dengan orang lain dalam membuat prestasi. Ia menganggap tidak akan berdaya melawan persaingan yang merugikan dirinya.

Sebaliknya, orang yang memiliki konsep diri positif ditandai dengan 5 hal, yaitu: 1) ia yakin akan kemampuannya mengatasi masalah; 2) ia merasa setara dengan orang lain; 3 ) ia menerima pujian tanpa rasa malu; 4) ia menyadari, bahwa setiap orang mempunyai berbagai perasaan, keinginan dan perilaku yang tidak seluruhnya disetujui masyarakat; 5) ia mampu memperbaiki dirinya karena ia sanggup mengungkapkan aspek-aspek kepribadian yang tidak disenangi dan berusaha mengubahnya (Ahman,1998).

Kemudian yang menjadi unsur final inti konsep diri adalah persepsi mental atau intelektual, yaitu yang meliputi: a) gambaran diri yang bersifat logic, berpikir rasional; b) gambaran diri yang berpandangan terbuka; c) gambaran diri sebagai murid yang berkemampuan; d) kepuasan 
terhadap ilmu pasti dan ilmu pengetahuan dan e) kemampuan membaca dan sebagainya.

Hasil penelitian Fitgerald dan Michael (dalam Somantri, 1996) menunjukkan bahwa sikap orang tua dan masyarakat merupakan salah satu sumber frustasi dan stres emosi bagi anak tunalaras. Terdapat dua sikap yang bertentangan, namun tidak disadari oleh mereka. Pertama, orang tua anak tunalaras sering memperlakukan anak mereka dengan sikap terlalu melindungi. Misalnya, dengan memenuhi segala keinginannya, dan melayani secara berlebihan. Bila perlu segala kebutuhannya tidak ada satu pun yang ditolak. Kedua, orang tua yang bersikap menolak kehadiran anak tersebut (Somantri, 2006). Kedua sikap orang tua tersebut sangat merugikan perkembangan anak tunalaras.

Hasil studi pendahuluan (lebih lanjut) melalui observasi maupun wawancara dengan guru tentang sikap orang tua terhadap anaknya, di antaranya ada yang bersikap terlalu melindungi dan ada sebagian yang lain bersikap acuh tak acuh, tidak atau kurang memperhatikannya, terutama kebutuhan psikisnya, seperti rasa kasih sayang, sedangkan mengenai kebutuhan yang sifatnya materi hampir sebagian besar memenuhinya. Dengan adanya kedua sikap orangtua tersebut, anak cenderung menjadi kurang mandiri, mudah tersinggung, dan semaunya sendiri.

\section{Metodologi}

Pendekatan yang digunakan dalam penelitian ini adalah pendekatan tindakan kolaboratif (Collaborative Action research). (Kemmis \& Taggart,1992: 87). Lokasi penelitian ini adalah di SLB-E (Tunalaras) Surabaya yang berstatus swasta dan beralamat di Jalan Dinoyo dan satu komplek dengan SDN Dinoyo IV Surabaya dan sebelumnya bernama SLB-E Prayuana. Jumlah guru di SLB-E 8 orang; 1 orang Kepala sekolah dan seorang Kaur Pendidikan. Mitra penelitian dalam hal ini adalah, wali kelas masing-masing kelas dan orang tua siswa.

Kegiatan penelitian dilakukan pada tahun ajaran 2008/2009 dan dilakukan dalam empat tahap. Pertama, tahap melihat kondisi di lapangan yang meliputi kegiatan apa yang selama ini dilakukan oleh guru, wali kelas dan orang tua dalam menjalankan layanan bimbingan konsep diri (self concept) di SLB-E (Tunalaras) Surabaya; bentuk-bentuk dukungan sistem yang diadakan untuk membantu pelaksanaan layanan bimbingan konsep diri yang dilakukan oleh wali kelas dan orang tua. Kedua, tahap merumuskan masalah di lapangan yang menjadi kepedulian wali kelas dan orang tua. Rumusan masalah ini disusun bersama wali kelas dan orang tua dengan cara diskusi. Adapun rumusan ini disusun berdasarkan hasil kegiatan pada tahap I (pertama). Ketiga, tahap merumuskan penerapan bimbingan konsep diri (self concept) yang dilakukan secara individual oleh wali kelas terhadap siswa yang mempunyai masalah penyimpangan perilaku sosial ada 4 siswa dengan mempertimbangkan kesesuaian antara data empirik, kurikulum, Program BP di SLB, teori bimbingan dan teori belajar. Keempat, implementasi (uji coba) cara layanan bimbingan konsep diri melalui wali kelas dan orang tua secara individual melalui langkah-langkah kegiatan Perencanaan; Tindakan/action; Observasi dan Refleksi berjalan secara siklus.

Teknik pengumpulan data yang dipergunakan dalam penelitian ini adalah wawancara, observasi, diskusi, simulasi dan uji coba. Analisis data diperlukan untuk memberi makna terhadap hasil penelitian, dilakukan dengan mengadakan interpretasi data secara logis dan rasional. Untuk menjaga objektivitas analisis data, dilakukan dua langkah. Pertama, Member check, yaitu dengan cara meminta sebagai mitra peneliti untuk mengecek kebenaran laporan yang sudah disusun. Untuk selanjutnya mengadakan perbaikan sesuai dengan saran dan masukan dari wali kelas yang dilibatkan dalam penelitian. Kedua, triangulasi, yaitu dilakukan dengan cara membandingkan hasil observasi dengan hasil wawancara dengan guru, wali kelas dan orang tua, juga membandingkan informasi masingmasing guru, wali kelas dan orang tua terhadap masalah yang sama.

\section{Hasil Penelitian dan Bahasan}

Hasil penelitian ini dapat ditarik kesimpulan sebagai berikut; kondisi objektif di sekolah menunjukkan bahwa siswa tunalaras di SLB/E Surabaya: masih belum optimal mendapat bimbingan konsep diri guna menumbuhkan 
kesadaran pentingnya diri dalam menempatkan diri, selain itu masih cukup banyak kendala dalam penanganan konsep diri melalui bimbingan terutama pada sistem pendidikan di SLB yang belum memandang perlu adanya fungsi Bimbingan Konseling. Dukungan sistem baik secara material maupun immaterial masih belum cukup untuk pengembangan bimbingan konseling yang kompleks sesuai tingkat kebutuhan anak. Perlunya penerapan bimbingan yang multiteknik dalam setiap penanganan kasus yang terjadi pada siswa termasuk persoalan konsep diri siswa tunalaras. Teknik-teknik yang diterapkan SLB/E Surabaya adalah desensitisasi sistematik, untuk mengeliminasi perilaku-perilaku siswa yang mengarah pada tindakan kebosanan, rational emotif terapi (RET) untuk menanggulangi keyakinan siswa tentang konsep diri yang tidak sesuai dengan kebutuhan dan kemampuannya, serta layanan informasi melalui kegiatan bermain peran, eksperimen bersama dan diskusi.

Pada subjek yang dikenakan dalam uji coba terbatas menunjukkan adanya perubahan konsep diri ke arah yang lebih positif: 1) frekuensi penyimpangan perilaku sosial semakin berkurang seperti berkata sopan, pakaian mulai rapi dsb; 2) siswa tidak lagi melakukan kebiasaan menunggu bimbingan guru kelasnya atau instrukturnya apabila mengerjakan tugas sekolah; 3 ) berdasarkan laporan dari orangtua siswa tidak lagi melakukan kebiasaan membiarkan pekerjaan yang ia kerjakan sendiri, tetapi mulai diringkas sendiri atau ditata seperti semula; dan 4) siswa mulai dapat memahami bahwa dirinya itu bagian dari lingkungan sekolah atau lingkungan keluarga.

Pada prinsipnya, jenis kasus penyimpangan perilaku sosial yang dilakukan oleh siswa Tunalaras di SLB/E Surabaya karena ketidakmengertian tentang hakikat konsep diri itu sendiri bagi siswa. Jenis bimbingan yang diberikan selama ini oleh guru tidak pernah dimaknai sebagai bimbingan konsep diri bagi siswa, seperti teguran, sanksi, dorongan belajar, dorongan berperilaku yang baik, dsb.

Konsep diri siswa tersebut muncul atau terjadi disebabkan oleh beberapa faktor yaitu dari faktor pembawaan (dari dalam) dan faktor dari luar (dari lingkungan). Faktor pembawaan (dari dalam) adalah sesuatu pengaruh yang dapat mengakibat- kan diri seseorang untuk berbuat atau berperilaku yang disebabkan oleh faktor kecerdasan yang rendah, cacat tubuh dan sebagainya. Faktor dari luar adalah segala pengaruh yang dapat mengakibatkan pada diri seseorang untuk berbuat misalnya: keluarga yang broken home atau retak, ketidak harmonisan serta faktor pendidikan yang kurang atau salah. Faktor pendidikan atau sikap yang diberikan orang tua yang terlalu melindungi terhadap anaknya, sehingga pendidikan berkesan serba boleh (permisif), misalnya; bentuk keterampilan yang diberikan di sekolah dianggap sebagai keterampilan yang tidak berarti, padahal perkembangan anak untuk dapat melakukannya saja adalah prestasi yang luar biasa.

Demikian juga sebaliknya mengenai pendidikan atau sikap yang diberikan kepada anaknya yang terlalu melarang atau orang tua bersikap cuek atau kurang perhatian terhadap anaknya atau serba tidak boleh dan bahkan menolak segala keinginannya, sehingga siswa di rumah akan menjadi tertekan pada perkembang-an kejiwaannya yang dapat mempengaruhi karir siswa. Hal ini sesuai dengan pendapatnya Fitgerald dan Michael (dalam Somantri, 2006) bahwa sikap orang tua merupakan salah satu sumber frustrasi dan stres emosi bagi anak tunadaksa.

Lebih lanjut hal ini sesuai dengan pendapat Surya (1994: 1) bahwa yang tergolong faktor pembawaan misalnya kelainan atau cacat tubuh, dan sebagainya. Yang tergolong faktor lingkungan adalah situasi keluarga yang kurang menunjang (misalnya rumah tangga yang retak, tidak utuh dan sebagainya), pendidikan keluarga yang tidak atau kurang baik, pergaulan yang salah dan sebagainya". Diperjelas Surya (1988: 1) bahwa "kemajuan ilmu pengetahuan dan teknologi di era globalisasi sekarang ini ikut pula memberikan pengaruh yang kuat bagi timbulnya penyimpangan".

Hal ini sesuai dengan pendapat Surya, (1994: 37), bahwa konseling merupakan kegiatan professional, artinya dilaksanakan oleh orang (konselor) yang telah memiliki kualifikasi profesional dalam pengetahuan, keterampilan, pengalaman dan kualitas

Mengenai strategi atau teknik layanan bimbingan yang diberikan di SLB/E Surabaya metodenya secara individual dan klasikal dan hal 
ini dilakukan apabila ada masalah siswa, maka diberikan layanan bimbingan, sehingga layanan bimbingan terkesan hanya secara insidental atau temporer dalam bentuk pemberian nasehat. Pada hal sebenarnya layanan bimbingan itu diberikan secara terencana dan menggunakan target waktu. Lebih lanjut Surya (1988:33) memberikan pengertian bimbingan yaitu suatu proses pemberian bantuan yang terus menerus dan sistematis dari pembimbing kepada yang dibimbing agar tercapai kemandirian dalam pemahaman diri, penerimaan diri, pengarahan diri dan perwujudan diri dalam mencapai tingkat perkembangan yang optimal dan penyesuaian diri dengan lingkungannya.

Surya (1988: 33) mengemukakan bahwa kegiatan bimbingan bukan merupakan suatu kegiatan yang dilakukan secara kebetulan, insidental, sewaktu-waktu, tidak sengaja atau asal saja, melainkan suatu kegiatan yang dilakukan dengan sistematis, sengaja, berencana, terus menerus dan terarah pada tujuan. Setiap kegiatan bimbingan merupakan kegiatan yang berkelanjutan, artinya senantiasa diikuti secara terus menerus dan aktif sampai sejauh mana individu telah berhasil mencapai tujuan dan menyesuaikan diri.

Berkaitan dengan kendala-kendala yang dihadapi oleh guru, wali kelas dan orang tua dalam melaksanakan bimbingan karir adalah meliputi: program layanan bimbingan konsep diri bagi siswa SLB, bahwa pada prinsipnya dari pihak wali kelas, guru, kepala sekolah maupun orang tua sudah memberikan secara individual yaitu bila ada permasalahan siswa yang sifatnya serius, namun bila masalahnya ringan maka hanya diberikan teguran atau nasehat.

Oleh karena itu pelaksana bimbingan pada umumnya dan khususnya bimbingan konsep diri bagi siswa SLB belum dapat berjalan secara sistematis, sehingga hasilnya juga belum optimal. Untuk menginginkan bimbingan berhasil dengan baik atau optimal maka bimbingan perlu dan harus diberikan secara sistematis/kontinyu dan berkelanjutan dengan menggunakan program. Hal ini sesuai dengan pendapat Miller, 1961 (dalam Natawidjaja, 1988), bahwa bimbingan merupakan tugas para ahli. Dalam penyusunan program dan pelaksanaan bimbingan khusus yang membutuh- kan keahlian tertentu, sekolah memerlukan para ahli di bidang tertentu, akan tetapi tidak semua dari tugas bimbingan itu harus dilakukan oleh ahli. Dalam hal tertentu seringkali peranan guru lebih menonjol daripada ahli terutama dalam pelaksanaan bimbingan di Sekolah Dasar, di mana guru sangat dekat dengan murid. Lebih lanjut bahwa bimbingan bukan semata-mata merupakan kegiatan yang menuntut keahlian khusus, melainkan suatu pelayanan bantuan yang membutuhkan sifat-sifat kepribadian yang memadai pada pihak yang memberikan bantuan itu.

Bila dilihat kewenangannya, yang mempunyai kewenangan sebagai tenaga bimbingan adalah konselor atau seseorang yang telah mendapatkan ilmu khusus mengenai bimbingan yaitu sarjana Bimbingan Penyuluhan. Walaupun tidak menutup kemungkinan bahwa di dalam bimbingan di sekolah juga mempunyai kewenangan memberikan bimbingan, asalkan memiliki pengetahuan, pengalaman, terampil dan berkepribadian baik yang dapat digunakan sebagai pelaksanaan tugas membimbing. Hal ini sesuai pendapat Natawidjaja (1988:27) bahwa untuk melaksanakan program bimbingan secara efisien dan efektif, sekolah perlu mempunyai petugas bimbingan yang memadai, baik mutunya maupun banyaknya.

Lebih lanjut Natawidjaja (1988:28), mengemukakan bahwa di dalam bimbingan di sekolah ada empat jenis petugas pendidikan yang memegang peranan yang sangat penting dalam pelaksanaan bimbingan. Adapun petugaspetugas itu adalah: a) kepala sekolah; b) guruguru bidang studi; c) penyuluh; dan d) guru penyuluh. Lebih lanjut dikatakan bahwa pada prinsipnya bimbingan ada empat kelompok prinsip bimbingan yang perlu diperhatikan dalam upaya melaksanakan bimbingan di lingkungan sekolah, yaitu: prinsip umum, prinsip yang berhubungan dengan individu yang dibimbing, prinsip yang berhubungan dengan yang membimbing, dan prinsip yang berhubungan dengan organisasi dan administrasi bimbingan. 


\section{Simpulan dan Saran}

\section{Simpulan}

Hasil penelitian ini dapat ditarik poin-poin simpulan sebagai berikut. Pertama, kondisi objektif di sekolah menunjukkan bahwa siswa tunalaras di SLB/E Surabaya masih belum optimal mendapat bimbingan konsep diri guna menumbuhkan kesadaran pentingnya diri dalam menempatkan diri. Kedua, kendala penanganan konsep diri melalui bimbingan masih cukup banyak terutama pada system pendidikan di SLB yang belum memandang perlu adanya fungsi Bimbingan Konseling. Ketiga,dukungan sistem baik secara material maupun immaterial belum mendukung pelaksanaan bimbingan konsep diri pada kebutuhan anak yang sangat kompleks. Keempat, perlunya penerapan bimbingan yang multiteknik dalam setiap penanganan kasus yang terjadi pada siswa termasuk persoalan konsep diri siswa tunalaras. Teknik-teknik yang diterapkan SLB/E Surabaya adalah desensitisasi sistematik, untuk mengeliminasi perilaku-perilaku siswa yang mengarah pada tindakan kebosanan, rational emotif terapy (RET) untuk menanggulangi keyakinan-keyakinan siswa tentang konsep diri yang tidak sesuai dengan kebutuhan dan kemampuannya, serta layanan informasi melalui kegiatan bermain peran, eksperimen bersama dan diskusi.

Pada subjek yang dikenakan dalam uji coba terbatas menunjukkan adanya perubahan konsep diri ke arah yang lebih positif seperti:1) frekuensi penyimpangan perilaku sosial semakin berkurang seperti berkata sopan, pakaian mulai rapi dsb; 2) siswa tidak lagi melakukan kebiasaan menunggu bimbingan guru kelasnya atau instrukturnya apabila mengerjakan tugas sekolah; 3) berdasarkan laporan dari orang tua siswa tidak lagi melakukan kebiasaan membiarkan pekerjaan yang ia kerjakan sendiri, tetapi mulai diringkas sendiri atau ditata seperti semula; 4) siswa mulai dapat memahami bahwa dirinya itu bagian dari lingkungan sekolah atau lingkungan keluarga.

\section{Saran}

Saran yang dirumuskan berdasarkan simpulan sebagai berikut. Pertama, bagi para pengawas. Pengawasan yang dilakukan sampai saat ini kepada guru dan wali kelas di SLB hanya kepada aspek administrasinya, penyusunan program pengajaran, pencapaian target kurikulum. Namun hendaknya dilakukan upaya untuk meningkatkan kualitas kegiatan bimbingan mingguan di luar kelas, dengan menekankan aspek membimbing. Pengawas agar turut serta mempopulerkan kegiatan bimbingan di SLB dengan melalui kegiatan yang ada misalnya: PKG maupun KKG, sehingga dapat menyemangati untuk membuat atau menyusun program bimbingan yang khususnya bimbingan konsep diri. Oleh karena itu pemberian materi bimbingan dapat diberikan secara terus menerus, karena pentingnya kegiatan bimbingan. Kedua, guru agar lebih jeli dan mencermati setiap permasalahan dari setiap siswa dengan menghimpun laporan baik dari siswa secara individual maupun secara kelompok guna melakukan tindakan preventif (pencegahan), kuratif (pengobatan) khususnya yang berkaitan dengan penyelarasan konsep diri siswa. Ketiga, kepada orang tua siswa, dalam hal ini orang tua hendaknya senantiasa menjalin kerja sama dengan sekolah, baik dengan guru, wali kelas kepada sekolah, sehingga dengan terjalinnya kerja sama maka akan terwujud dalam bentuk komunikasi "Plan of Action, dan Program Layanan Bimbingan Konsep diri Siswa SLB" yang baik dengan pihak sekolah sehingga bimbingan konsep diri siswa yang dilakukan di sekolah juga ada kelanjutannya di rumah (sehingga terjadilah kesepahaman dan kontinyuitas baik di sekolah dan di rumah).

\section{Pustaka Acuan}

Ahman. 1998. Bimbingan Perkembangan: Model Bimbingan dan Konseling di SD (Studi kasus kea rah penemuan model bimbingan pada beberapa SD di Jawa Barat). Disertasi. PPS IKIP Bandung (tidak diterbitkan)

Chauhan,S. 1979. Advencen Educational Psychology. New Delhi: Vikars Publishing House,Pvt.Ltp.

Depdikbud. 1999. Kurikulum Pendidikan Luar Biasa (Pedoman Bimbingan di Sekolah): Jakarta.

De Polito,Carolyn M. 1997. Interpersonal Communication. California: Cummings Publishing Company. 
Gergen,K.J. 1965. Interaction Goals and Personalistic Feedback as Factors Affecting the Presentation of Self. Journal of Personality and Sosial Psychology, $1: 413-424$.

Kaufman, James M. 1997. Exceptional Children Introduction to Special Education. London: Prestice Hall International Inc.

Kemmis,S \& Mc. Taggart,R. 1992. The Action Research Planne. Victoria: deaken University.

Natawidjaja, R. 1988. Pedoman Guru dalam Bimbingan di Sekolah. Bandung: FIP IKIP Bandung.

Somantri, S. 2006. Psikologi Anak Luar Biasa. Jakarta: Depdikbud Dirjen Dikti.

Sullivan, H.S. 1953. The Interpersonal Theory of Psychiatry. New York: Norton.

Surya, M. 1988. Dasar-dasar Penyuluhan (Konseling). Jakarta: Depdikbud. Direktorat Jendral Pendidikan Tinggi; Proyek Pengembangan Lembaga Pendidikan Tenaga Kependidikan.

Surya, M. 1994. Dasar-dasar dan Teori Konseling Pendidikan. Bandung: Bhakti Winaya.

Winzer. M. 1990. Children with exceptionalities. Canadian Perspective Prentice - Hall Inc: Canada. 